\title{
DISEMINASI TEKNOLOGI PENGOLAHAN SAMPAH TERPADU DI KABUPATEN PURWOREJO
}

\author{
Rosiana Indrawati ${ }^{1}$, Fifin Hindarti ${ }^{2}$, Amallia Puspitasari ${ }^{3}$ \\ ${ }^{1,2,3}$ Program Studi Teknik Energi Fakultas Teknologi Industri \\ Institut Teknologi Yogyakarta \\ Jalan Winong Tinalan Kotagede \\ Email : ${ }^{1}$ Rosiana.Indrawati@gmail.com
}

\begin{abstract}
Abstrak
Sampah rumah tangga merupakan salah satu sumber sampah yang cukup besar peranannya dalam pencemaran lingkungan. Masyarakat selaku produsen sampah masih kurang tingkat kepeduliannya terhadap pengelolaan sampah. Mitra dalam hal ini adalah Pemerintah Desa Bandungrejo dan Karang Taruna "Muda Jaya" RT 02 RW 04 Desa Bandungrejo Kecamatan Bayan Kabupaten Purworejo berinisiatif untuk dapat mengelola sampah yang mereka hasilkan sehingga tidak berbahaya bagi lingkungan sekaligus dapat menambah pendapatan dari penjualan sampah yang sudah diolah. Berdasarkan latar belakang tersebut, pengusul mempunyai ide gagasan untuk mengembangkan teknologi pengolahan sampah yang dapat dimanfaatkan oleh mitra melalui Program Penerapan Teknologi Tepat Guna (PPTTG) kerjasama Kementerian Riset, Teknologi dan Pendidikan Tinggi dengan DPR RI Komisi X. Kegiatan yang dilakukan yaitu memberikan bantuan berupa mesin pengolah sampah terpadu sekaligus pelatihan pengolahan sampah. Alat-alat yang diberikan antara lain satu unit mesin pencacah plastik, satu unit mesin pencacah organik, satu unit mesin pengayak organik, 20 set tempat sampah terpilah, 20 unit komposter dan bantuan dana untuk pembangunan bangunan pengolah sampah untuk penempatan mesin-mesin tersebut. Kegiatan ini diharapkan dapat memecahkan permasalahan mitra dalam pengelolaan sampah dan meningkatkan kesejahteraan masyarakat sendiri.
\end{abstract}

Kata kunci: sampah, organik, plastik, Kabupaten Purworejo.

\begin{abstract}
Household waste is one of the sources of waste which has a big role in environmental pollution. The community as a waste producer still lacks a high level of concern for waste management itself. Partners in this case are Bandungrejo Village Youth and Youth Youth Association of "Jaya Jaya" RT 02 RW 04 Bandungrejo Village Bayan District Purworejo District initiative to be able to manage the waste they produce so that it is not harmful to the environment while at the same time adding value to the income from the sale of processed waste. So in this case, the proposer has ideas to develop waste processing technology that can be utilized by partners in this case the community through the Appropriate Technology Application Program (PPTTG) in collaboration with the Ministry of Research, Technology and Higher Education with the House of Representatives Commission X. Activities undertaken i.e. to provide assistance in the form of an integrated waste processing machine as well as a waste management training. The tools provided include one unit of a plastic chopper machine, one unit of an organic chopper machine, one unit of an organic sieving machine, 20 unit of sorted waste bins, 20 units of composter and financial assistance for the construction of a waste processing building for the placement of these machines. This activity
\end{abstract}


is expected to solve the problems of partners in waste management and improve the welfare of the community itself.

Keywords: garbage, organic,plastic, Purworejo Regency

\section{Latar Belakang Masalah}

Sampah merupakan salah satu permasalahan lingkungan yang memerlukan perhatian serius. Sampah adalah suatu bahan yang terbuang atau dibuang dari sumber hasil aktivitas manusia maupun proses alam yang belum memiliki nilai ekonomis. Sampah yang dibuang ke lingkungan dapat menjadi beban bagi lingkungan. Secara umum jenis sampah dapat dibedakan menjadi 2 (dua), yaitu sampah organik/basah dan sampah anorganik/kering. Seiring meningkatnya jumlah penduduk, maka volume sampah di lingkungan juga ikut bertambah. Keberadaan sampah dapat bersumber dari rumah tangga, kegiatan pertanian, kegiatan pembangunan dan pemugaran gedung, daerah perdagangan, maupun lembaga pendidikan [1].

Sampah rumah tangga merupakan salah satu sumber sampah yang cukup besar peranannya dalam pencemaran lingkungan. Keberadaan sampah rumah tangga di suatu lingkungan memang tidak bisa dihindari. Keberadaan sampah dapat menimbulkan pencemaran tanah dan air, menimbulkan bau tidak sedap, menjadi sarang binatang yang merupakan sumber penyakit, serta mengganggu keindahan, namun demikian keberadaan sampah dapat dikurangi dan dikendalikan (diminimalkan). Upaya sederhana yang dapat dilakukan untuk meminimalkan sampah rumah tangga adalah melakukan pemilahan antara sampah organik dan sampah anorganik. Sampah organik dapat dijadikan kompos, sedangkan sampah plastik dapat dijadikan bahan baku industri plastik dengan dilakukan pengolahan terlebih dahulu [1].

Bandungrejo adalah salah satu desa yang berada di Kecamatan Bayan Kabupaten Purworejo. Desa Bandungrejo berjarak $+1 \mathrm{~km}$ dari ibukota Kecamatan Bayan dan $+13 \mathrm{~km}$ dari ibukota Kabupaten. Desa Bandungrejo terdiri dari 4 Dusun, 5 RW dan 12 RT dengan jumlah penduduk 2.652 jiwa yang terdiri dari 1.329 laki-laki dan 1.323 perempuan serta kepadatan penduduk mencapai 1,702 per $\mathrm{km}$ wilayah. Sebagian besar wilayah di Desa Bandungrejo ditanami palawija dan sebagian kecil ditanam padi dan jagung. Sebagian besar warga masyarakatnya bekerja di sektor pertanian, peternakan dan sebagai pegawai pemerintahan.

Kaitannya dengan persampahan, warga masyarakat yang berada di RT 02 RW 04 Desa Bandungrejo Kecamatan Bayan Kabupaten Purworejo juga merupakan bagian dari masyarakat yang menghasilkan sampah rumah tangga setiap hari. Sampah rumah tangga sebagian besar merupakan bahan organik. Termasuk sampah organik, misalnya sampah dari dapur berupa sisa tepung, sayuran, kulit buah, dan daun. Selain itu sampah rumah tangga juga berupa bahan anorganik, misalnya berupa botol kaca, botol plastik, tas plastik, dan kaleng.ntuk mengatasi sampah yang mereka hasilkan.

Jumlah sampah tersebut selama ini hanya dikelola dengan cara dikumpulkan kemudian diangkut petugas sampah untuk dibawa ke TPA atau dikelola oleh karang taruna setempat, pengelolaan hanya sebatas dilakukan pemilahan kemudian menjual sampah yang masih bernilai ekonomi untuk menambah kas karang taruna. Masyarakat lainnya masih melakukan pembakaran sampah yang tentunya berdampak semakin buruk terhadap kondisi lingkungan yaitu menimbulkan pencemaran udara. Kepedulian masyarakat selama ini hanya sebatas mengumpulkan sampah yang mereka hasilkan ditempat sampah masing-masing. Sebagian besar warga masyarakat belum mengetahui tentang pemilahan sampah dari sumber untuk meminimalkan timbulan sampah dan mengolah sampah di sumbernya.

Upaya meminimalkan sampah dapat dilakukan dengan 3R, meliputi reduce (mengurangi), reuse (pakai ulang), dan recycle (daur ulang). Upaya tersebut dilandasi 
pemikiran bahwa setiap orang berhak atas lingkungan yang layak dan nyaman, sehingga setiap orang wajib menjaga kenyamanan lingkungan, tanpa kecuali. Sampah yang diolah dapat mengurangi timbulan sampah yang masuk ke Tempat Pemrosesan Akhir Sampah yang berarti juga mendukung program kerja pemerintah daerah setempat dalam partisipasi pengelolaan lingkungan dari bahaya sampah. Selain itu, sampah yang diolah dapat memiliki manfaat tertentu dan bernilai ekonomi sehingga dapat menambah penghasilan keluarga. Misal sampah organik diproses menjadi kompos yang dapat digunakan untuk pupuk dan dapat dijual. Begitu pula dengan sampah organik seperti plastik bila diolah lebih lanjut dapat dijadikan bahan baku industri yang menggunakan plastik sehingga dapat meningkatkan kesejahteraan masyarakat [2].

Berdasarkan uraian di atas, maka dipandang perlu untuk dilakukan Pembuatan Teknologi Mesin Pengolah Sampah yang dapat dimanfaatkan oleh mitra yaitu Pemerintah Desa Bandungrejo dan Karang Taruna "Muda Jaya" RT 02 RW 04 Desa Bandungrejo Kecamatan Bayan Kabupaten Purworejo dalam menangani sampah domestik yang mereka hasilkan.

\section{Masalah}

Beberapa permasalahan yang teridentifikasi di lokasi yang akan menjadi fokus rencana kegiatan bersama dengan mitra antara lain:

a. Pengelolaan sampah masih kurang mendapat penanganan yang optimal sehingga menimbulkan berbagai permasalahan lingkungan.

b. Peran masyarakat dalam pengelolaan sampah kebanyakan masih sebatas membuang sampah di tempat yang seharusnya atau belum pada pengolahan sampah yang memberikan manfaat kembali bagi masyarakat.

c. Masih rendahnya pengetahuan masyarakat tentang pengelolaan sampah organik dan plastik menjadi produk bernilai tinggi.

Berdasarkan identifikasi permasalahan yang telah menjadi bahasan bersama dengan mitra, maka pengusul menawarkan solusi permasalahan yaitu pembuatan teknologi pengolahan sampah yang fokus pada sampah organik dan plastik. Teknologi tersebut meliputi mesin pencacah plastik, mesin pencacah sampah organik, mesin pengayak kompos. Dengan penerapan teknologi tepat guna pengolahan sampah tersebut diharapkan dapat mengurangi jumlah timbulan sampah khususnya di Desa Bandungrejo Kecamatan Bayan. Selain itu, teknologi tersebut dapat meningkatkan nilai ekonomi sampah organik dan plastik sehingga dapat mensejahterakan kehidupan masyarakat. Sampah organik dapat diolah menjadi kompos sedangkan sampah plastik yang diolah kembali akan menjadi biji plastik yang bernilai ekonomi tinggi.

Adanya kepedulian dari pemerintah desa Bandungrejo dan Karang Taruna "Muda Jaya" RT 02 RW 04 Desa Bandungrejo untuk meminimalkan sampah rumah tangga tentunya sangat membantu meminimalkan timbunan sampah keseluruhan yang masuk di lingkungan.

\section{Metode}

Untuk mencapai target luaran yang direncanakan, metode pelaksanaan program yang akan diterapkan adalah sebagai berikut:

1. Penerapan teknologi pengembangan mesin pengolahan sampah

- Sistem penerapan teknologi mesin pengolahan sampah adalah serangkaian proses pengembangan teknologi mesin mulai dari mengindentifikasi kebutuhan, perancangan dan pembuatan mesin, pengujian operasional mesin sampai dengan pendampingan dan pelatihan operasional mesin pengolah sampah pada masyarakat. 
- Penerapan teknologi mesin pengolahan sampah secara bertahap akan dilakukan pada satu mitra, dimana mitra yang menjadi pilot projectnya adalah Pemerintah Desa Bandungrejo dan Karang Taruna "Muda Jaya" RT 02 RW 04 Bandungrejo, Kecamatan Bayan, Kabupaten Purworejo. Keberhasilan penerapan pada pilot project ini, diharapkan dapat dilanjutkan pada skala yang lebih luas pada tahun selanjutnya.

- Sistem penerapan yang akan dilakukan sebagai berikut :

- Identifikasi kebutuhan Mitra.

Identifikasi kebutuhan mitra yang disesuaikan dengan rencana kapasitas produksi Hal ini berkaitan dengan pendalaman data mengenai:

- Profil Mitra secara keorganisasian, untuk mendapat memetakan permasalahan Mitra dalam hal pengolahan sampah baik organik maupun anorganik.

- Kapasitas produksi Mitra. Untuk dapat melihat sejauh mana pengembangan dan peningkatan kapasitas produksi hasil yang akan disesuaikan dengan jangkauan pemasaran mitra.

- Jangkauan Pemasaran Mitra. Dengan mengetahui jangkauan pasar dapat disinkronkan dengan rencana kapasitas maksimum hasil yang dapat kembangkan pada mesin olahan tersebut.

- Perancangan dan Pembuatan Mesin.

Tahap ini dialokasikan waktu selama 2 bulan yaitu bulan Juli sampai dengan Agustus. Setelah mendapatkan detail informasi mengenai profil mitra maka dilanjutkan pada modifikasi teknologi yaitu pengembangan mesin pengolahan yang dimulai dari desain perancangan kapasitas produksi dan pembuatan mesin [4].

- Mendesain pengembangan mesin pengolahan sampah. Melakukan re-desain terhadap teknologi yang telah ada melalui peningkatan kapasitas produksi mesin olahan sampah

- Membuat mesin pengolahan sampah. Membuat mesin pengolahan sampah berdasarkan dengan desain yang telah direkayasa sebelumnya.

- Pengujian Operasional Mesin.

Setelah pembuatan mesin selesai dilakukan maka dilanjutkan dengan tahapan berikutnya yaitu melakukan pengujian terhadap operasional mesin tersebut. Tahapan pengujian ini dilakukan untuk melihat kehandalan dari mesin yang telah dibuat. Adapun langkah-langkah yang dilakukan adalah sebagai berikut:

- Melakukan pengujian operasional mesin di bengkel

- Melakukan pengujian operasional mesin di masyarakat

- Melakukan evaluasi terhadap hasil uji mesin di masyarakat

- Teknologi yang akan diterapkan adalah sebagai berikut:

1. Pencacah Plastik

- P.1.t 800x500x1200mm

- Penggerak em $0.5 \mathrm{hp} 350 \mathrm{wtt}$

- Kap 50 kg.jam

- Penggerak diesel 12 hp rrt

- Rangka unp 80

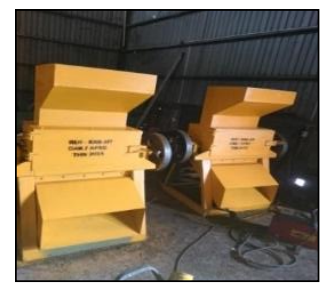

- Jumlah pisau gerak pisau, pisau diam 4 pisau

- Saringan $12 \mathrm{~mm}$ 
2. Pencacah Organik

- P.l.t 1200x600x1200mm

- Penggerak diesel rrt 12 pk

- Kapasitas $750 \mathrm{~kg}$

- Diameter tabung $380 \mathrm{~mm}$

- Panjang $600 \mathrm{~mm}$

- Tebal $3 \mathrm{~mm}$ dan $6 \mathrm{~mm}$

- Corong tebal 1,7 mm

- Rangka unp 60

- Jumlah pisau gerak 27 pcs

- Jumlah pisau diam 18 pcs

3. Pengayak Kompos

- P.l.t 3000x1000x1200 mm

- Penggerak dinamo $1 \mathrm{hp}$

- Kapasitas 750 kg.jam

- Rangka siku 50

- Bahan ayakan stainless steel $6 \mathrm{~mm}$
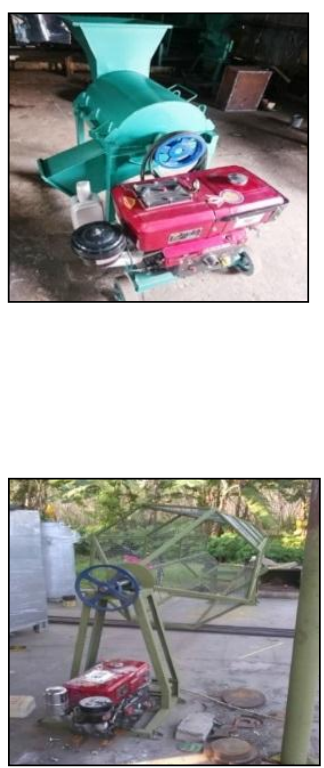

2. Penguatan Kelembagaan (Capacity Building) dan Sumber Daya

Kegiatan ini direncanakan selama tiga bulan yaitu bulan Agustus sampai dengan Oktober, dimulai dari kegiatan FGD dan sosialisasi dilanjutkan pelatihan.

- Kegiatan penguatan kelembagaan dilakukan melalui proses sosialisasi dan Focus Group Discussion (FGD) untuk penerapan mesin pengolahan sampah dengan melibatkan semua pihak yang terkait.

- Selain itu, untuk peningkatan kompetensi sumber daya manusia, terutama pelaku usaha pengolahan sampah di Kabupaten Purworejo dan warga masyarakat, akan dilakukan pelatihan proses pengolahan sampah organik dan plastik dengan berbasis teknologi mesin pengolahan sampah sesuai dengan bagian masing-masing. Melalui pelatihan ini, diharapkan mereka memahami apa yang harus dilakukan di lapangan dalam mengimplementasikan program ini.

- Keterlibatan mitra diharapkan berupa perilaku kewirausahaan pelaku usaha di Kabupaten Purworejo, serta pendampingan kegiatan baik selama program PPTTG berjalan maupun selesai, agar keberhasilan usaha pelaku usaha pengolahan sampah ini berjalan berkesinambungan dan bisa diterapkan di daerah lain di Indonesia [6].

\section{Hasil Yang Dicapai}

\subsection{Sosialisasi Dan Serah Terima Alat Pengolah Sampah}

Kegiatan sosialisasi dilaksanakan pada tanggal 26 Agustus 2019 bertempat di Gedung Pertemuan Desa Bandungrejo yang berlokasi persis di pinggir jalan Raya KutoarjoPurworejo. Dalam kegiatan sosialisasi ini dihadiri oleh Anggota DPR RI Bapak Ir.Bambang Sutrisno mewakili DPR RI Komisi X. Hadir pula narasumber sosialisasi dari Institut Teknologi Yogyakarta Dr.Drs.Nasirudin, M.S. selain itu, acara sosialisasi juga mengundang beberapa Dinas terkait antara lain Dinas Lingkungan Hidup dan Dinas Pembangunan Desa. Segenap Muspika, perangkat desa dan pengurus PKK juga turut hadir dalam kegiatan sosialisasi ini. 


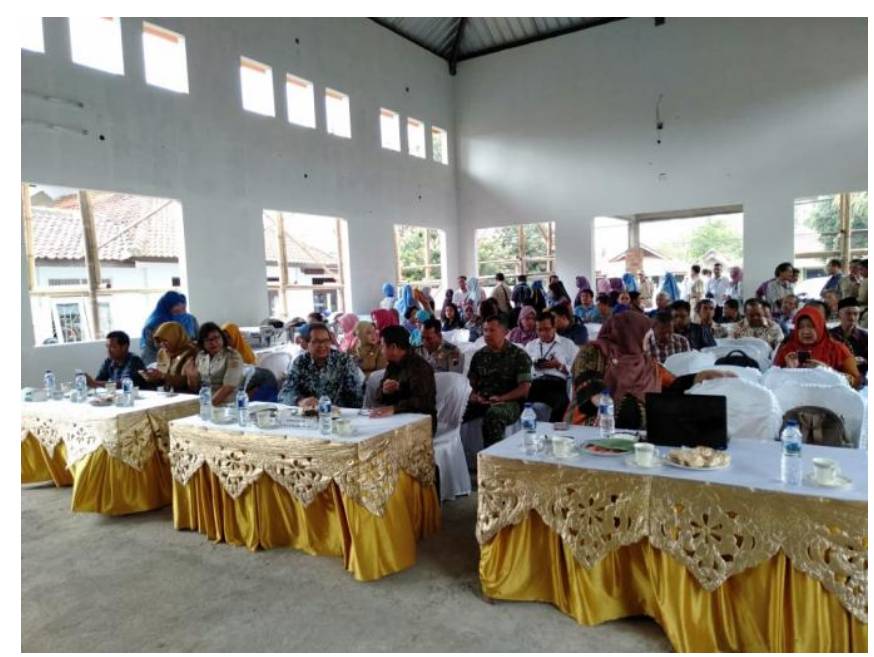

Gambar 1. Peserta Sosialisasi

Selanjutnya yaitu acara penandatanganan Berita Acara Serah Terima Alat yang disampaikan oleh Perwakilan DPR RI komisi X kepada Ketua Tim Pengusul PPTTG dari Institut Teknologi Yogyakarta kemudian kepada Kepala Desa dan Karang Taruna Muda Jaya Desa Bandungrejo. Teknologi dan bantuan yang diberikan antara lain berupa :

1. Satu unit mesin pencacah organik

2. Satu unit mesin pengayak organik

3. Satu unit mesin pencacah plastik

4. Dua puluh komposter

5. Dua puluh set tempat sampah terpilah

6. Bantuan dana untuk bangunan pengolah sampah dan lantai kerja untuk penempatan alat.

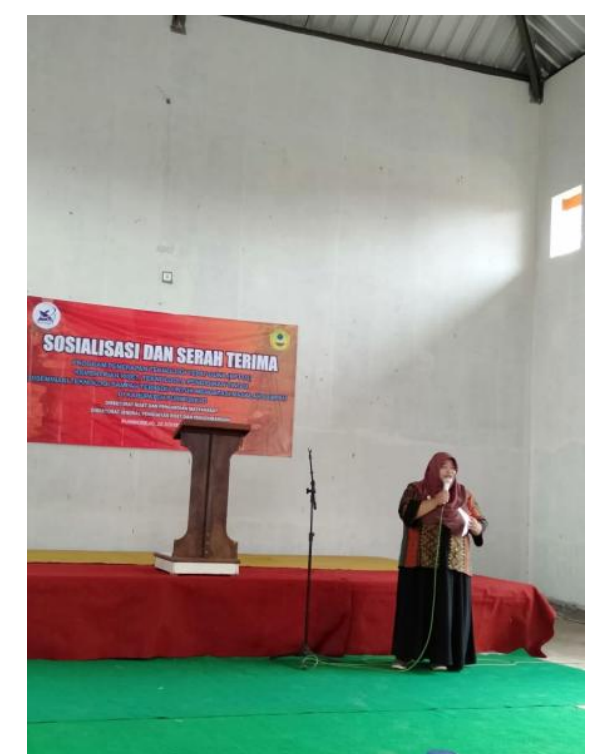

Gambar 2. Sambutan Ketua Pengusul 


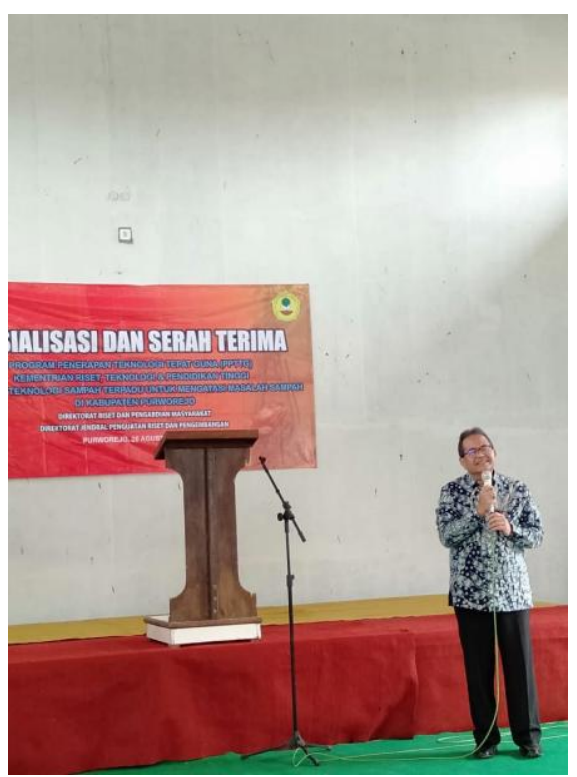

Gambar 3. Sambutan Perwakilan DPR RI Komisi X Bambang Sutrisno

Dalam sambutannya, Bambang Sutrisno menyampaikan bahwa masyarakat Bandungrejo harus bangun dari tidurnya dalam pengelolaan sampah. Masyarakat harus mulai mengolah sampah mereka sendiri jika mereka ingin Purworejo aman dari permasalahan sampah. Program ini sudah lama digagas dan tereasilisasi pada tahun 2019.

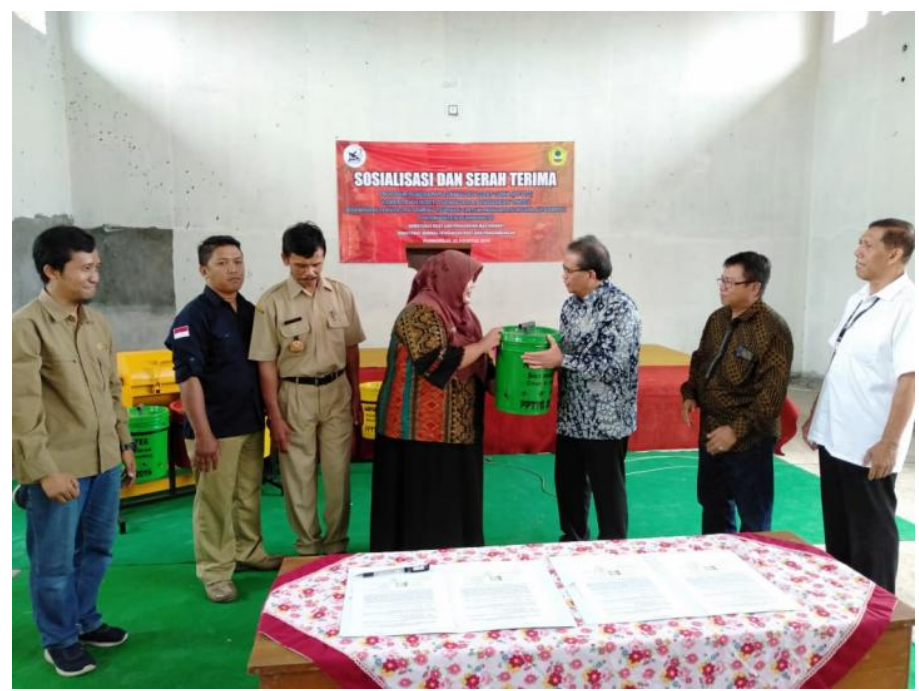

Gambar 4. Serah Terima Alat dari DPR RI Komisi X Kepada Ketua Pengusul PPTTG dari ITY 


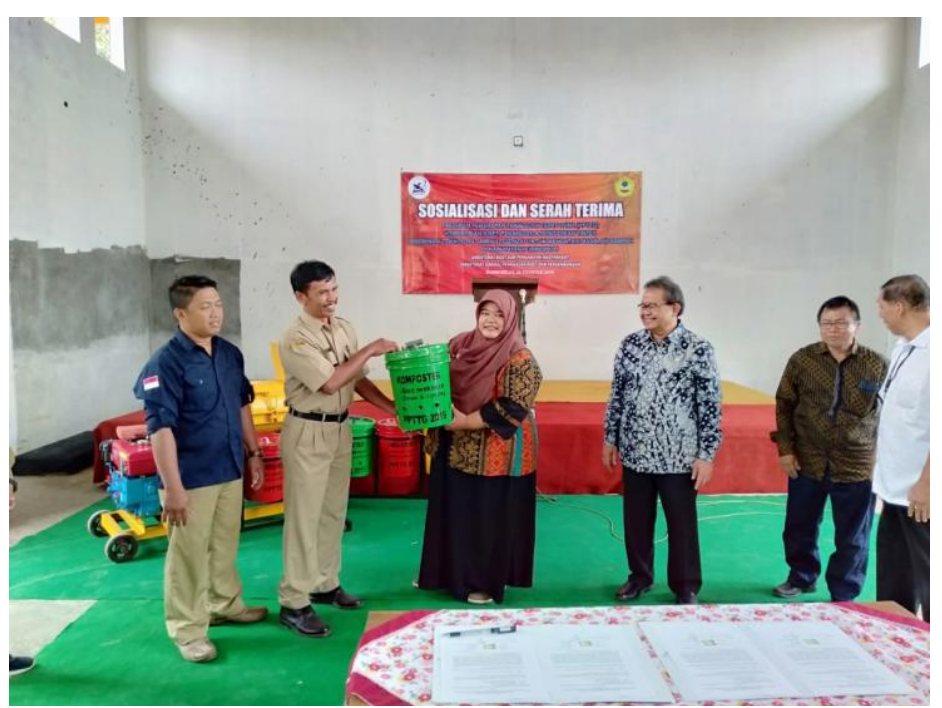

Gambar 5. Serah Terima Alat dari Ketua Pengusul Kepada Pemerintah Desa Bandungrejo

Sementara itu, Maria Dhini mewakili Dinas Lingkungan Hidup Kabupaten Purworejo dalam sambutannya menyampaikan DLH Purworejo akan siap mendampingi dan memantau jalannya pengolahan sampah di Desa Bandungrejo. Purworejo sudah memiliki TPA dengan sistem Controlled Landfill dan mempunyai umur pakai yang pendek, sehingga dengan adanya kegiatan mengolah sampah dari sumbernya yang dilakukan oleh masyarakat Desa Bandungrejo akan mengurangi timbulan sampah yang dibuang ke TPA.

Narasumber sosialisasi Dr.Nasirudin menyampaikan bahwa pengolahan sampah harus melibatkan masyarakat. Kegiatan ini harus mampu memunculkan pemberdayaan masyarakat. Mesin-mesin tersebut mungkin akan mangkrak jika tidak ada manusia yang mengoperasikannya. Sehingga sangat penting untuk masyarakat mengetahui dan terlibat langsung dalam pengolahan sampah menggunakan alatalat TTG ini. Sampah yang telah diolah akan dapat meningkatkan ekonomi atau nilai jual dari sampah tersebut. Maka, secara tidak langsung akan meningkatkan kesejahteraan masyarakat Desa Bandungrejo.

Masyarakat Desa Bandungrejo sangat antusias dan berterima kasih khususnya kepada Kementerian Riset, Teknologi dan Pendidikan Tinggi dan kepada Perwakilan DPR RI komisi $X$. Hal tersebut disampaikan oleh Kepala Desa Bapak Maman pada saat menyampaikan sambutan. Harapannya adalah dengan adanya mesin pengolah sampah terpadu ini, maka Desa Bandungrejo dapat memberdayakan masyarakatnya untuk mengolah sampah dan dapat menjadi bagian dari masyarakat peduli lingkungan yang ikut berpartisipasi mendukung program pemerintah mengurangi dan menanggulangi sampah.

\section{Kesimpulan}

Adapun kesimpulan yang dapat diperoleh adalah:

1. Kegiatan pengabdian ini dilaksanakan dalam bentuk pemberian bantuan alat dan pelatihan pengolahan sampah terpadu berbasis masyarakat.

2. Kegiatan dapat dikatakan berhasil, karena dapat terlaksana dengan baik dan respon masyarakat yang tinggi yang terlihat dari keaktifan peserta selama diskusi dan kegiatan berlangsung.

\section{Daftar Pustaka}

[1] Damanhuri, E. (2004). Diktat Kuliah pengelolaan Persampahan. Institut Teknologi Bandung. Bandung 
[2] Ni Komang Ayu Artiningsih. (2008). Peran Serta Masyarakat dalam Pengelolaan Sampah Rumah Tangga (Studi Kasus di Sampangan dan Jomblang, Kota Semarang). Tesis.UNDIP. Semarang

[3] Undang-Undang Republik Indonesia No. 18 Tahun 2008 tentang Pengelolaan Sampah.

[4] Styana, U. I. F., Hindarti, F., Ardito, M. N., \& Cahyono, M. S. (2019). Penerapan Teknologi Pengolahan Sampah Plastik menjadi Bahan Bakar Minyak untuk Mengatasi Masalah Sampah di Kota Bandung. KACANEGARA Jurnal Pengabdian pada Masyarakat, 2(1), 1-6.

[5] Wardoyo, W. (2016). Membandingkan Kinerja Mesin Bensin Dua Langkah Satu Silinder pada Sepeda Motor Menggunakan Variasi Campuran Bahan Bakar Minyak Hasil Proses Pirolisis Sampah Plastik dan Premium dengan Premium Murni. Angkasa: Jurnal Ilmiah Bidang Teknologi, 8(2), 57-64.

[6] Widoyoko, S. E. P., \& Arifin, H. D. (2014). Pengelolaan sampah secara terpadu berbasis ekonomi kreatif di desa Krendetan, Bagelen, Purworejo.

[7] Kamariah, K., \& Sukirman, S. (2018). Diversifikasi Pengolahan Dan Pengembangan Produk Kelapa Untuk Industri Kecil Masyarakat Desa Ngampel Kecamatan Pituruh Purworejo.

[8] Yogiesti, V., Hariyani, S., \& Sutikno, F. R. (2012). Pengelolaan sampah terpadu berbasis masyarakat Kota Kediri. Jurnal Tata Kota dan Daerah, 2(2), 95-102.

[9] Dwiyanto, B. M. (2011). Model peningkatan partisipasi masyarakat dan penguatan sinergi dalam pengelolaan sampah perkotaan. Jurnal Ekonomi Pembangunan: Kajian Masalah Ekonomi dan Pembangunan, 12(2), 239-256.

[10] Mulasari, S. A., Husodo, A. H., \& Muhadjir, N. (2014). Kebijakan pemerintah dalam pengelolaan sampah domestik. Kesmas: National Public Health Journal, 8(8), 404-410. 
Rosiana Indrawati, Fifin Hindarti, Amallia Puspitasari 